\title{
Editorial \\ Environmental Stressors and Pathology of Marine Molluscs
}

\author{
Giuseppe Esposito (D), Paolo Pastorino*(D) and Marino Prearo \\ The Veterinary Medical Research Institute for Piemonte, Liguria and Valle d'Aosta, Via Bologna 148, \\ 10154 Torino, Italy; giuseppe.esposito@izsto.it (G.E.); marino.prearo@izsto.it (M.P.) \\ * Correspondence: paolo.pastorino@izsto.it; Tel.: +39-011-268-6251
}

Keywords: mollusc; bivalve; gastropod; climate changes; biomarkers; alien species; bioindicators; environmental contaminates; mollusc diseases; marine biotope

\section{Introduction}

Mollusca is one of the most species-rich phylum of the Animal Kingdom, comprising a wide range of both terrestrial and aquatic organisms. Molluscs generally show a soft body mostly enclosed within a hard shell with a protective role. However, even if they share a similar basic body plan, the group often shows great variability and diversity in form and habit [1,2]. Of the more than 70,000 recently described species, roughly 44,000 show worldwide distribution in seas [3], although bivalves and gastropods have expanded their distribution also in freshwater ecosystems. This last class is present in all terrestrial ecosystems except for permanent ice.

The main classes of molluscs include the Class Gastropoda ( $\sim 40,000$ species; e.g., abalone, conches, periwinkles, whelks, limpets, land snails and slugs, etc.), the Class Bivalvia ( $\sim 8000$ species; e.g., mussels, oysters, clams, etc.), the Class Cephalopoda ( 700 species; e.g., octopus, squid, cuttlefish, etc.), and the Classes Polyplacophora and Scaphopoda ( 1000 species; i.e., chitons and tusk shells, respectively).

However, while some pelagic taxa have ocean-wide distribution, others such as nonmarine taxa (i.e., terrestrial and freshwater) are threatened by anthropogenic activities due to their narrow to extreme endemism [4]. Indeed, freshwater and terrestrial molluscs species are the leading group in the red list of many countries, so included on the IUCN Red List [5-7]. Therefore, in this regard, we can state that organisms in their natural environments are often subjected to continuous environmental stress conditions, whose synergistic interaction with anthropogenic stressors (e.g., chemical, etc.) can amplify their effects [8] — but what does the term stress mean?

It is difficult to give an exhaustive explanation of the word "stress". However, an early definition of stress was proposed by Selye $[9,10]$, and then overhauled by several authors over the years [11-20]. In brief, the concept shared by all authors is that stress can be defined as a physiological response of the organism to a stressor (i.e., the variable that causes this response). Indeed, depending on the level of intensity and duration of exposure, stress is observed as a threat to homeostasis, even in organisms with higher tolerance and plasticity [21]. Thus, the perception of a stressor promotes an immediate response: positive effects (eustress) if the stress is of mild intensity, and adaptive responses with possible maladaptive or negative implications (distress) if generated by greater severities [22]. This concept has since been fully investigated in recent years. In fact, many scientists have turned their attention to hormesis, closely related to the initial disruption of homeostasis [23]. Therefore, an adaptive biological response of an organism to moderate stress is defined as hormesis [24]. This phenomenon is a useful tool to study dose-response relationships, as low-dose exposures (to multiple chemical and physical agents) promote protective/beneficial effects in contrast to higher doses [25], as well as providing important

Copyright: (C) 2022 by the authors Licensee MDPI, Basel, Switzerland. This article is an open access article distributed under the terms and conditions of the Creative Commons Attribution (CC BY) license (https:// creativecommons.org/licenses/by/ $4.0 /)$. information on biological plasticity (i.e., environmental hormesis) [26]. 
In addition, exposure to one or more etiologic agents (e.g., physical, chemical, biological, etc.) may expose invertebrates to disease [27-29]. The effects and interactions between pollution and pathogens can have significant effects on the ecology and physiology of both farmed and wild molluscs [30].

\subsection{Physical and Biological Factors}

Physical factors (i.e., temperature, salinity, and hydrographic features) affect spatial distribution as well as biological aspects including feeding, reproduction, growth, respiration, osmoregulation, and parasite-disease interactions [2]. However, the synergistic effect with other environmental variables (e.g., depth, substrate type, food availability, turbidity, etc.) may have greater consequences than a single factor.

In addition, molluscs are usually preyed upon by different groups of organisms (e.g., fish, birds, mammals, crustaceans, echinoderms, flatworms, etc.) [2,31,32]. Predators probably represent the most important cause of natural mortality, also capable of influencing population growth and size structure in addition to overall abundance and local distribution patterns [2,33-35].

\subsection{Climate Change}

Climate change is global long-term shifts in average temperature conditions and weather patterns, directly or indirectly attributable to anthropogenic activities. Global warming will therefore have serious implications for natural and human systems [36]. In the coming years, different intensities of ocean warming, acidification, oxygen depletion, or productivity shortfalls will simultaneously affect the global ocean surface [37].

Thus, the main effect of warming will be to shift the distribution of species based on their metabolic temperature tolerances [38-42], and warming will also have important effects on biotic factors [2].

In this context, another important aspect is ocean acidification. Increased levels of atmospheric $\mathrm{CO}_{2}$ result in increased levels of dissolved $\mathrm{CO}_{2}$ in the oceans, thereby reducing the availability of carbonate ions essential for calcifying marine organisms such as molluscs [43]. Another serious consequence of global warming is the decrease in dissolved $\mathrm{O}_{2}$ content in the world's oceans [44]. Thus, the synergy of the above-mentioned stressors can have serious implications on survival, growth, and metamorphosis, especially during the larval stages of molluscs [45].

\subsection{Alien Species Introduction}

Invasive alien species (IAS) are organisms introduced by humans, either accidentally or intentionally, outside their area of origin. Often, they are key drivers of serious longterm direct and indirect impacts on both the environment and human life. Therefore, IAS represent the second most common cause of biodiversity loss after habitat destruction [46].

Synergies with other drivers of global changes promote invasions with serious implication on native species, communities, and ecosystems [47], through mechanisms such as competition, predation, hybridization, disease transmission, parasitism, burrowing activity, and rooting [48].

For instance, Strayer [49] highlighted the negative effects that some IAS (i.e., aquatic plants, fish, crustaceans, and molluscs) have on native mollusc populations. The most striking example is that of the zebra mussel (Dreissena polymorpha), able to completely change the physicochemical properties and structure of the invaded environment as well as change the structure of the entire animal and plant community [49].

\subsection{Environmental Contaminants}

Molluscs, particularly gastropods and bivalves, are suitable organisms (bioindicators) to assess the contamination levels of terrestrial, freshwater, and marine ecosystems worldwide [50-54]. This fact is related to some important features such as their widespread distribution, abundance, sedentary habits, body size, and, often, their ecological and/or 
economic relevance [55]. For instance, these features enabled the development of the "Mussel Watch Program" (MWP), namely the longest running continuous and upgraded monitoring program for chemical contaminants and biological indicators of water quality, based on the collection and analysis of bivalves and sediments [56,57]. Thus, management, surveillance, and monitoring are of paramount importance as the pollutants may have adverse effects on populations of benthic assemblages ranging from changes in structure to decline and local extinction, including impacts on public health [58].

Therefore, molluscs' responses to environmental stress and contaminants have been investigated by several authors [59-68], including related pathological aspects [28,69].

\subsection{Major Disease-Causing Agents}

The major disease-causing agents of marine molluscs are bacteria, viruses, fungi, protozoans, trematodes, turbellarians, nematodes, and parasitic crustaceans [70]. These pathologies can have important impacts on wildlife populations, fisheries, and aquaculture industries. However, due to the preciousness and economic importance of bivalve molluscs, there is a lot of information about the diseases that affect them, both inherent to farmed and wild species (e.g., [28,71-79]), also being frequently reported as vectors responsible for diseases in humans [80-83].

Molluscs are usually bred in estuarine and coastal environments often contaminated by human activities [2,84]. Their filtering ability makes these organisms biological accumulators capable of concentrating various pathogens in their tissues [2].

Journal of Marine Science and Engineering has dedicated a Special Issue to marine molluscs, focused on environmental stressors and their effects, including pathology. Contributions should be original articles on the following topics:

- Environmental pressures: alien species introduction and environmental contaminates;

- (Eco)toxicological studies;

- The use of new bioindicators/tracers of environmental contamination;

- The condition and structure of mollusc populations;

- $\quad$ Factors affecting geographic distribution (physical, chemical, and biological factors);

- Climate change (e.g., climate warming, acidification, hypoxia);

- Change in feeding attitude (e.g., filtration rate, particle processing, absorption efficiency);

- $\quad$ Factors affecting reproduction, settlement, and recruitment;

- $\quad$ Factors affecting natural populations and cultured molluscs (e.g., bacterial and viral infections, biotoxins, pollutants);

- Major disease-causing agents (e.g., bacteria, viruses, fungi, or parasites);

- Defense mechanisms of marine molluscs.

The aim is to stimulate and collect new research data on marine molluscs, especially bivalves, from around the world. For more information, please contact the editors.

Author Contributions: G.E., P.P. and M.P. These authors contributed equally to this work. All authors have read and agreed to the published version of the manuscript.

Funding: This research received no external funding.

Institutional Review Board Statement: Not applicable.

Informed Consent Statement: Not applicable.

Data Availability Statement: Not applicable.

Conflicts of Interest: The authors declare no conflict of interest. 


\section{References}

1. Gosling, E. Bivalve Molluscs-Biology, Ecology and Culture. In Fishing News Books; Blackwell Science: Oxford, UK, 2003; pp. $1-455$.

2. Gosling, E. Bivalve Molluscs—Second Edition. In Fishing News Books; Blackwell Science: Oxford, UK, 2015 ; pp. 1-513.

3. Rosenberg, G. A New Critical Estimate of Named Species-Level Diversity of the Recent Mollusca. Am. Malacol. Bull. 2014, $32,308$. [CrossRef]

4. Haszprunar, G. Phylum mollusca. In Invertebrate Zoology: A Tree of Life Approach; Schierwater, B., DeSalle, R., Eds.; CRC Press: Boca Raton, FL, USA, 2021; p. 301.

5. Kay, A.K. The Conservation Biology of Molluscs: Proceedings of a Symposium Held at the 9th International Malacological Congress; IUCN: Edinburgh, UK, 1986.

6. Lydeard, C.; Cowie, R.H.; Ponder, W.; Bogan, A.; Bouchet, P.; Clark, S.A.; Cummings, K.S.; Frest, T.J.; Gargominy, O.; Herbert, D.G.; et al. The Global Decline of Nonmarine Mollusks. BioScience 2004, 54, 321-330. [CrossRef]

7. Neubert, E.; Seddon, M.B.; Allen, D.J.; Arrébola, J.; Backeljau, T.; Balashov, I.; Bank, R.; Cameron, R.; de Frias Martins, A.M.; De Mattia, W.; et al. European Red List of Terrestrial Molluscs; IUCN: Cambridge, UK; Brussels, Belgium, 2019. Available online: https: / / portals.iucn.org/library/node/48439 (accessed on 13 January 2022).

8. Holmstrup, M.; Bindesbøl, A.-M.; Oostingh, G.J.; Duschl, A.; Scheil, V.; Köhler, H.-R.; Loureiro, S.; Soares, A.; Ferreira, A.; Kienle, C.; et al. Interactions between effects of environmental chemicals and natural stressors: A review. Sci. Total Environ. 2010, 408, 3746-3762. [CrossRef]

9. Selye, H. The Physiology and Pathology of Exposure to Stress, A Treatise Based on the Concepts of the General-Adaptation Syndrome and the Diseases of Adaptation; Acta Medical Publishers: Montreal, QC, Canada, 1950.

10. Selye, H. The Evolution of the Stress Concept: The originator of the concept traces its development from the discovery in 1936 of the alarm reaction to modern therapeutic applications of syntoxic and catatoxic hormones. Am. Sci. 1973, 61, 692-699.

11. Brett, J.R. Implications and assessments of environmental stress. In Investigations of Fishpower Problems; Larkin, P.A., MacMillan, H.R., Eds.; Lectures in Fisheries; University of British Columbia: Vancouver, BC, Canada, 1958; pp. 69-83.

12. Bayne, B.L.; Gabbott, P.A.; Widdows, J. Some effects of stress in the adult on the eggs and larvae of Mytilus edulis L. J. Mar. Biol. Assoc. 1975, 55, 675-689. [CrossRef]

13. Wedemeyer, G.A.; McLeay, O.J. Methods for determining the tolerance of fishes to environmental stressors. In Stress Fish; Pickering, A.D., Ed.; Academic Press: Cambridge, CA, USA, 1981; pp. 247-275.

14. Bayne, B.L. Ecological consequences of stress. In The Effects of Stress and Pollution on Marine Animals; Bayne, B.L., Ed.; Praeger Publishers: New York, NY, USA, 1985; pp. 141-157.

15. Barton, B.A.; Iwama, G.K. Physiological changes in fish from stress in aquaculture with emphasis on the response and effects of corticosteroids. Annu. Rev. Fish Dis. 1991, 1, 3-26. [CrossRef]

16. Barton, B.A. Stress in finfish: Past, present and future-A historical perspective. In Fish Stress and Health in Aquaculture; Iwama, G.K., Pickering, A.D., Sumpter, J.P., Schreck, C.B., Eds.; Cambridge University Press: Cambridge, UK, 1997; pp. 1-33.

17. Chrousos, G.P. Stressors, Stress, and Neuroendocrine Integration of the Adaptive Response: The 1997 Hans Selye Memorial Lecture. Ann. N. Y. Acad. Sci. 1998, 851, 311-335. [CrossRef]

18. Chrousos, G.P. Stress and disorders of the stress system. Nat. Rev. Endocrinol. 2009, 5, 374-381. [CrossRef]

19. Schreck, C.B. Accumulation and long-term effects of stress in fish. Biol. Anim. Stress 2000, 1, 147-158. [CrossRef]

20. Koolhaas, J.; Bartolomucci, A.; Buwalda, B.; de Boer, S.; Flügge, G.; Korte, S.M.; Meerlo, P.; Murison, R.; Olivier, B.; Palanza, P.; et al. Stress revisited: A critical evaluation of the stress concept. Neurosci. Biobehav. Rev. 2011, 35, 1291-1301. [CrossRef]

21. Schulte, P.M. What is environmental stress? Insights from fish living in a variable environment. J. Exp. Biol. 2014, 217, 23-34. [CrossRef]

22. Schreck, C.B.; Tort, L. The concept of stress in fish. In Fish Physiology; Academic Press: Cambridge, MA, USA, 2016; Volume 35, pp. 1-34.

23. Ray, S.; Farris, F.; Hartmann, A.C.H. Encyclopedia of Toxicology, 3rd ed.; Wexler, P., Ed.; Academic Press: Cambridge, MA, USA, 2014; pp. 944-948. [CrossRef]

24. Mattson, M.P. Hormesis defined. Ageing Res. Rev. 2008, 7, 1-7. [CrossRef]

25. Agathokleous, E.; Kitao, M.; Calabrese, E.J. Environmental hormesis and its fundamental biological basis: Rewriting the history of toxicology. Environ. Res. 2018, 165, 274-278. [CrossRef]

26. Agathokleous, E. Environmental hormesis, a fundamental non-monotonic biological phenomenon with implications in ecotoxicology and environmental safety. Ecotoxicol. Environ. Saf. 2018, 148, 1042-1053. [CrossRef]

27. McClellan-Green, P.D. Endocrine Disruption in Molluscs: Processes and Testing. In Endocrine Disrupters; Wiley: Hoboken, NJ, USA, 2013; pp. 143-184.

28. Carella, F.; Feist, S.; Bignell, J.; DE Vico, G. Comparative pathology in bivalves: Aetiological agents and disease processes. J. Invertebr. Pathol. 2015, 131, 107-120. [CrossRef]

29. Shaw, J.; Moore, M.; Readman, J.; Mou, Z.; Langston, W.; Lowe, D.; Frickers, P.; Al-Moosawi, L.; Pascoe, C.; Beesley, A. Oxidative stress, lysosomal damage and dysfunctional autophagy in molluscan hepatopancreas (digestive gland) induced by chemical contaminants. Mar. Environ. Res. 2019, 152, 104825. [CrossRef]

30. Morley, N. Interactive effects of infectious diseases and pollution in aquatic molluscs. Aquat. Toxicol. 2010, 96, 27-36. [CrossRef] 
31. Cotton, P.A.; Rundle, S.D.; Smith, K.E. Trait Compensation in Marine Gastropods: Shell Shape, Avoidance Behavior, and Susceptibility to Predation. Ecology 2004, 85, 1581-1584. [CrossRef]

32. Romeo, T.; Battaglia, P.; Pedà, C.; Perzia, P.; Consoli, P.; Esposito, V.; Andaloro, F. Pelagic cephalopods of the central Mediterranean Sea determined by the analysis of the stomach content of large fish predators. Helgol. Mar. Res. 2011, 66, 295-306. [CrossRef]

33. Crowl, T.A.; Covich, A.P. Predator-Induced Life-History Shifts in a Freshwater Snail. Science 1990, 247, 949-951. [CrossRef]

34. Turner, A.M.; Montgomery, S.L. Spatial and Temporal Scales of Predator Avoidance: Experiments with Fish and Snails. Ecology 2003, 84, 616-622. [CrossRef]

35. Gerlach, J.; Barker, G.M.; Bick, C.S.; Bouchet, P.; Brodie, G.; Christensen, C.C.; Collins, T.; Coote, T.; Cowie, R.H.; Fiedler, G.C.; et al Negative impacts of invasive predators used as biological control agents against the pest snail Lissachatina fulica: The snail Euglandina 'rosea' and the flatworm Platydemus manokwari. Biol. Invasions 2021, 23, 997-1031. [CrossRef]

36. Hoegh-Guldberg, O.; Jacob, D.; Bindi, M.; Brown, S.; Camilloni, I.; Diedhiou, A.; Djalante, R.; Ebi, K.; Engelbrecht, F.; Guiot, J.; et al Impacts of $1.5^{\circ} \mathrm{C}$ Global Warming on Natural and Human Systems. In Global Warming of $1.5^{\circ} \mathrm{C}$. An IPCC Special Report; Masson-Delmotte, V., Zhai, P., Pörtner, H.O., Roberts, D., Skea, J., Shukla, P.R., Pirani, A., Moufouma-Okia, W., Péan, C., Pidcock, R., et al., Eds.; IPCC Secretariat: Geneva, Switzerland, 2018; pp. 175-311.

37. Mora, C.; Wei, C.-L.; Rollo, A.; Amaro, T.; Baco, A.R.; Billett, D.; Bopp, L.; Chen, Q.; Collier, M.; Danovaro, R.; et al. Biotic and Human Vulnerability to Projected Changes in Ocean Biogeochemistry over the 21st Century. PLoS Biol. 2013, 11, e1001682. [CrossRef] [PubMed]

38. Root, T.L.; Price, J.T.; Hall, K.R.; Schneider, S.H.; Rosenzweigk, C.; Pounds, J.A. Fingerprints of global warming on wild animals and plants. Nature 2003, 421, 57-60. [CrossRef]

39. Cordellier, M.; Pfenninger, A.; Streit, B. Assessing the effects of climate change on the distribution of pulmonate freshwater snail biodiversity. Mar. Biol. 2012, 159, 2519-2531. [CrossRef]

40. Beltramino, A.A.; Vogler, R.; Gregoric, D.E.G.; Rumi, A. Impact of climate change on the distribution of a giant land snail from South America: Predicting future trends for setting conservation priorities on native malacofauna. Clim. Chang. 2015, 131, 621-633. [CrossRef]

41. Albano, P.G.; Steger, J.; Bošnjak, M.; Dunne, B.; Guifarro, Z.; Turapova, E.; Hua, Q.; Kaufman, D.S.; Rilov, G.; Zuschin, M. Native biodiversity collapse in the eastern Mediterranean. Proc. R. Soc. B Boil. Sci. 2021, 288, 20202469. [CrossRef]

42. Schickele, A.; Francour, P.; Raybaud, V. European cephalopods distribution under climate-change scenarios. Sci. Rep. 2021, 11, 1-12. [CrossRef]

43. Fabry, V.J.; Seibel, B.A.; Feely, R.A.; Orr, J. Impacts of ocean acidification on marine fauna and ecosystem processes. ICES J. Mar. Sci. 2008, 65, 414-432. [CrossRef]

44. Keeling, R.F.; Körtzinger, A.; Gruber, N. Ocean Deoxygenation in a Warming World. Annu. Rev. Mar. Sci. 2010, 2, 199-229. [CrossRef]

45. Gobler, C.J.; DePasquale, E.L.; Griffith, A.W.; Baumann, H. Hypoxia and Acidification Have Additive and Synergistic Negative Effects on the Growth, Survival, and Metamorphosis of Early Life Stage Bivalves. PLoS ONE 2014, 9, e83648. [CrossRef]

46. Wilson, E.O. The Future of Life; Vintage Books: New York, NY, USA, 2003; p. 256.

47. Pyšek, P.; Hulme, P.E.; Simberloff, D.; Bacher, S.; Blackburn, T.M.; Carlton, J.T.; Dawson, W.; Essl, F.; Foxcroft, L.C.; Genovesi, P.; et al. Scientists' warning on invasive alien species. Biol. Rev. 2020, 95, 1511-1534. [CrossRef] [PubMed]

48. Tricarico, E.; Inghilesi, A.F.; Brundu, G.; Iiriti, G.; Loi, M.C.; Caddeo, A.; Carnevali, L.; Genovesi, P.; Carotenuto, L.; Monaco, A. Le Specie Aliene Invasive: Cosa e Come Comunicare al Grande Pubblico. Guida Tecnica Per Operatori Didattici di Orti Botanici, Zoo, Musei Scientifici, Acquari e Aree Protette. LIFE ASAP ISBN 2018, 978-988. Available online: https://www.lifeasap.eu/ index.php/it/ (accessed on 5 January 2022).

49. Strayer, D. Effects of Alien Species on Freshwater Mollusks in North America. J. N. Am. Benthol. Soc. 1999, 18, 74-98. [CrossRef]

50. Baroudi, F.; Al Alam, J.; Fajloun, Z.; Millet, M. Snail as sentinel organism for monitoring the environmental pollution; a review. Ecol. Indic. 2020, 113, 106240. [CrossRef]

51. Esposito, G.; Meloni, D.; Abete, M.C.; Colombero, G.; Mantia, M.; Pastorino, P.; Prearo, M.; Pais, A.; Antuofermo, E.; Squadrone, S. The bivalve Ruditapes decussatus: A biomonitor of trace elements pollution in Sardinian coastal lagoons (Italy). Environ. Pollut. 2018, 242, 1720-1728. [CrossRef]

52. Esposito, G.; Mudadu, A.G.; Abete, M.C.; Pederiva, S.; Griglione, A.; Stella, C.; Ortu, S.; Bazzoni, A.M.; Meloni, D.; Squadrone, S. Seasonal accumulation of trace elements in native Mediterranean mussels (Mytilus galloprovincialis Lamarck, 1819) collected in the Calich Lagoon (Sardinia, Italy). Environ. Sci. Pollut. Res. 2021, 28, 25770-25781. [CrossRef]

53. Pastorino, P.; Prearo, M.; Anselmi, S.; Menconi, V.; Bertoli, M.; Dondo, A.; Pizzul, E.; Renzi, M. Use of the Zebra Mussel Dreissena polymorpha (Mollusca, Bivalvia) as a Bioindicator of Microplastics Pollution in Freshwater Ecosystems: A Case Study from Lake Iseo (North Italy). Water 2021, 13, 434. [CrossRef]

54. Pastorino, P.; Nocita, A.; Ciccotelli, V.; Zaccaroni, A.; Anselmi, S.; Giugliano, R.; Tomasoni, M.; Silvi, M.; Menconi, V.; Vivaldi, B.; et al. Health Risk Assessment of Potentially Toxic Elements, Persistence of NDL-PCB, PAHs, and Microplastics in the Translocated Edible Freshwater Sinotaia quadrata (Gasteropoda, Viviparidae): A Case Study from the Arno River Basin (Central Italy). Expo. Health 2021, 13, 583-596. [CrossRef]

55. Oehlmann, J.; Schulte-Oehlmann, U. Molluscs as bioindicators. In Trace Metals and Other Contaminants in the Environment; Elsevier: Amsterdam, The Netherlands, 2003; pp. 577-635. 
56. Apeti, D.A.; Wirth, E.F.; Leight, A.; Mason, A.L.; Pisarski, E. An Assessment of Contaminants of Emerging Concern in Chesapeake Bay, MD and Charleston Harbor, SC; NOAA Technical Memorandum NOS NCCOS 240; Silver Spring, MD, USA; Washington, DC, USA, 2018; pp. 1-104. [CrossRef]

57. Apeti, D.A.; Johnson, W.E.; Kimbrough, K.L.; Lauenstein, G.G. National Status and Trends Mussel Watch Program: Sampling Methods 2012 Update; NOAA Technical Memorandum NOS NCCOS 134; Silver Spring, MD, USA; Washington, DC, USA, 2012 ; pp. 1-39. Available online: https:/ / repository.library.noaa.gov/view/noaa/16903 (accessed on 6 January 2022).

58. Islam, S.; Tanaka, M. Impacts of pollution on coastal and marine ecosystems including coastal and marine fisheries and approach for management: A review and synthesis. Mar. Pollut. Bull. 2004, 48, 624-649. [CrossRef]

59. Bayne, B.L.; Moore, M.N.; Widdows, J.; Livingstone, D.R.; Salkeld, P.; Crisp, D.J.; Morris, R.J.; Gray, J.S.; Holden, A.V.; Newell, R.C.; et al. Measurement of the responses of individuals to environmental stress and pollution: Studies with bivalve molluscs. Philos. Trans. R. Soc. B: Biol. Sci. 1979, 286, 563-581. [CrossRef]

60. Bresler, V.; Abelson, A.; Dizer, H.; Sturm, A.; Kratke, R.; Fishelson, L.; Hansen, P.-D.; Bissinger, V. Marine molluscs and fish as biomarkers of pollution stress in littoral regions of the Red Sea, Mediterranean Sea and North Sea. Helgol. Mar. Res. 1999, 53, 219-243. [CrossRef]

61. Manduzio, H.; Rocher, B.; Durand, F.; Galap, C.; Leboulenger, F. The point about oxidative stress in molluscs. Invertebr. Surviv. J. 2005, 2, 91-104.

62. Coutellec, M.A.; Caquet, T. Gastropod Ecophysiological Response to Stress. In Physiology of Molluscs: A Collection of Selected Reviews, Two-Volume Set; Saleuddin, S., Mukai, S., Eds.; CRC Press: Boca Raton, FL, USA, 2017; pp. 303-396.

63. El-Gendy, K.; Gad, A.; Radwan, M. Physiological and behavioral responses of land molluscs as biomarkers for pollution impact assessment: A review. Environ. Res. 2021, 193, 110558. [CrossRef]

64. Primost, M.; Averbuj, A.; Bigatti, G.; Márquez, F. Embryonic shell shape as an early indicator of pollution in marine gastropods Mar. Environ. Res. 2021, 167, 105283. [CrossRef] [PubMed]

65. Chahouri, A.; Agnaou, M.; El Hanaoui, M.; Yacoubi, B.; Moukrim, A.; Banaoui, A. Assessment of seasonal and spatial variation responses of integrated biomarkers in two marine sentinel bivalve species: Agadir Bay (Southern of Morocco). Mar. Pollut. Bull. 2021, 174, 113179. [CrossRef] [PubMed]

66. Zaidi, M.; Athmouni, K.; Metais, I.; Ayadi, H.; Leignel, V. The Mediterranean limpet Patella caerulea (Gastropoda, Mollusca) to assess marine ecotoxicological risk: A case study of Tunisian coasts contaminated by metals. Environ. Sci. Pollut. Res. 2022, 1-20. [CrossRef] [PubMed]

67. Ajala, M.; Ben Ameur, W.; Annabi, A. First evidence of the utility of cephalopods for biomonitoring program in the field: Case of Sepia officinalis south west of Mediterranean Sea (Gulf of Gabes, Tunisia). Environ. Sci. Pollut. Res. 2022, 1-13. [CrossRef] [PubMed]

68. Ferreira, G.V.; Justino, A.K.; Eduardo, L.N.; Lenoble, V.; Fauvelle, V.; Schmidt, N.; Junior, T.V.; Frédou, T.; Lucena-Frédou, F. Plastic in the inferno: Microplastic contamination in deep-sea cephalopods (Vampyroteuthis infernalis and Abralia veranyi) from the southwestern Atlantic. Mar. Pollut. Bull. 2022, 174, 113309. [CrossRef]

69. Costa, P.M.; Carreira, S.; Costa, M.H.; Caeiro, S. Development of histopathological indices in a commercial marine bivalve (Ruditapes decussatus) to determine environmental quality. Aquat. Toxicol. 2013, 126, 442-454. [CrossRef]

70. Santhanam, R. Biology and Ecology of Edible Marine Gastropod Molluscs; CRC Press: Boca Raton, FL, USA, 2018.

71. Bower, S.M.; McGladdery, S.E.; Price, I.M. Synopsis of infectious diseases and parasites of commercially exploited shellfish. Annu. Rev. Fish Dis. 1994, 4, 1-199. [CrossRef]

72. Ford, S.E. Pests, parasites, diseases, and defense mechanisms. In The Biology of the Hard Clam, Mercenaria mercenaria (Linné); Kraeuter, J.N., Castagna, M., Eds.; Elsevier Science Publishers B.V.: Amsterdam, The Netherlands, 2001; pp. 591-628.

73. Cremonte, F.; Figueras, A.; Burreson, E.M. A histopathological survey of some commercially exploited bivalve molluscs in northern Patagonia, Argentina. Aquaculture 2005, 249, 23-33. [CrossRef]

74. Mcgladdery, S.E.; Bower, S.M.; Getchell, R.G. Diseases and parasites of scallops. In Scallops: Biology, Ecology and Aquaculture; Shumway, S.E., Parsons, G.J., 2nd, Eds.; Elsevier Science Publishers B.V.: Amsterdam, The Netherlands, 2006 ; pp. 595-650.

75. Renault, T. Shellfish viruses. In Encyclopedia of Virology; Mahy, B.W.J., Van Regenmortel, M.H.V., Eds.; Elsevier: Oxford, UK, 2008; pp. 560-567.

76. Beaz-Hidalgo, R.; Balboa, S.; Romalde, J.L.; Figueras, M.J. Diversity and pathogenecity of Vibrio species in cultured bivalve molluscs. Environ. Microbiol. Rep. 2010, 2, 34-43. [CrossRef] [PubMed]

77. Guo, X.; Ford, S.E. Infectious diseases of marine molluscs and host responses as revealed by genomic tools. Philos. Trans. R. Soc. B Biol. Sci. 2016, 371, 20150206. [CrossRef] [PubMed]

78. Zannella, C.; Mosca, F.; Mariani, F.; Franci, G.; Folliero, V.; Galdiero, M.; Tiscar, P.G.; Galdiero, M. Microbial Diseases of Bivalve Mollusks: Infections, Immunology and Antimicrobial Defense. Mar. Drugs 2017, 15, 182. [CrossRef] [PubMed]

79. Sindermann, C.J. Interactions of Pollutants and Disease in Marine Fish and Shellfish. In Pathobiology of Marine and Estuarine Organisms; CRC Press: Boca Raton, FL, USA, 2021; pp. 451-482.

80. Rippey, S.R. Infectious diseases associated with molluscan shellfish consumption. Clin. Microbiol. Rev. 1994, 7, 419-425. [CrossRef] [PubMed]

81. Fayer, R.; Trout, J.; Lewis, E.; Santin, M.; Zhou, L.; Lal, A.; Xiao, L. Contamination of Atlantic coast commercial shellfish with Cryptosporidium. Parasitol. Res. 2003, 89, 141-145. [CrossRef] 
82. Zhang, M.; Yang, Z.; Wang, S.; Tao, L.; Xu, L.; Yan, R.; Song, X.; Li, X. Detection of Toxoplasma gondii in shellfish and fish in parts of China. Vet. Parasitol. 2014, 200, 85-89. [CrossRef]

83. Xu, L.; Cai, J.; Gao, T.; Ma, A. Shellfish consumption and health: A comprehensive review of human studies and recommendations for enhanced public policy. Crit. Rev. Food Sci. Nutr. 2021, 1-13. [CrossRef]

84. Helm, M.M.; Bourne, N.; Lovatelli, A. Hatchery Culture of Bivalves: A Practical Manual; FAO Fisheries Technical Papers, No. 471; FAO: Rome, Italy, 2004. Available online: https:/ / www.fao.org/3/y5720e/y5720e.pdf (accessed on 3 January 2022). 